\title{
Reluctant Feminists, Powerless Patriarchs, and Estranged Spectators: Gender in Post-1989 Eastern European Cinema
}

\author{
Elżbieta Ostrowska ${ }^{1 *}$
}

Published: September 8, 2020

\begin{abstract}
The article analyses several films made within Eastern Europe during the first decade of the postcommunist period that represent the crisis of traditional gender models which permeated popular cinema. As the author argues the films represent 'transition cultures' in regard to gender discourse. The film Ildikó Enyedi's $M y$ Twentieth Century (Az én XX. századom, Hungary/GDR/ Cuba, 1989) destabilises normative models of femininity by means of both the narrative content and formal strategies. Dorota Kędzierzawska's Nothing (Nic, Poland, 1998) and Ildikó Szabó's, Child Murders (Gyerekgyillkosságok, Hungary, 1993) denounce its discriminatory politics, especially effective on women that represent marginalised sectors of society. Finally, The Garden (Zábrada, Slovakia, France, 1995) directed by Martin Šulík, demonstrates how breaking with the code of realism facilitates the process of 'correction of patriarchy'. The article will establish that these films significantly disrupt the national and thus patriarchal mode of address. This shift from the national to the gendered mode of identification also marks a new point of encounter between Eastern European and Western feminism. Due to represented gender uncertainty and aesthetic modes of spectatorial distanciation, the analysed works indicate this resistance and scepticism towards any singular mode of identification.
\end{abstract}

Keywords: post communism, Eastern European cinema, Eastern European feminism, women's cinema, postcommunist cinema

\section{INTRODUCTION}

"Love is when your legs are trembling, when your lips are wet, and that's a state, which I love, which I need," says Anka, the female protagonist of Barbara Sass-Zdort's film Like a Drug (Jak narkotyk, Poland, 1999). With these words, she discards romantic and sublime concepts of love and speaks of it in erotic terms. She openly expresses female desire. Throughout the film, Anka searches for language that will express both her femininity and bodily agency. The protagonist of Like a Drug, not unlike many women in Eastern Europe during the aftermath of the collapse of communism, struggles over her body.

In this article I will discuss how Eastern European cinema addressed women's struggle over their subjective agency in the first decade of postcommunism. First, I will locate the issue within political and social contexts with a special emphasis on upsurge of anti-feminist sentiments in the region. As I will establish, at that time Eastern European feminism defined itself through the negation of a communist concept of gender equality as well as Western feminism. Arguably, the first decade of postcommunism witnessed a complex process of women's struggle over their political and bodily agency and their relationship with (heterosexual) nation. Eastern European cinema responded to the ideological struggles over femininity in ambivalent ways. Its mainstream strand reflected anti-feminist sentiments, whereas art cinema addressed ideological and political uncertainty over the concept of femininity. The films I will be analysing in the main part of the article offer an important testimony to the struggle over gender that took place in the first decade of postcommunism. Their aesthetic and ideological ambiguity helps to understand the complexity of political and cultural transitions that took place at that time in the region. 


\section{AND BEYOND}

The euphoric mood initially engendered in Eastern Europe by the political upheaval of 1989 soon changed to disillusionment. Eastern European women especially had many reasons for these negative sentiments. As Slavenka Drakulić states:

When the changes began in Yugoslavia in 1989, women were in the streets along with men, demonstrating, meeting, holding flags and banners, shouting, singing, and voting. But when it came to forming new governments, when it came to direct participation in power, they disappeared, became invisible again. (1993: 123)

Polish women were even more disillusioned as

[w] hat emerged from the Quiet Revolution of 1989 in Poland was a highly traditional culture, rooted in religious fundamentalism, nationalist ideology and patriarchal practices. (Filipowicz, 2001: 4)

When in March 1990 Solidarity accepted and supported a total ban on abortion, Polish women faced discrimination, which was unprecedented in the era of state socialism. Apparently, in new democratic Poland, and other Eastern European countries for that matter, women were not beneficiaries of the newly achieved freedom.

Cultural production, including cinema, participated in the process of shifting gender discourse to regressive positions. Rapidly developing in the region, popular cinema employed various generic formulas with a visible tension between 'male genres', such as gangster and crime drama, and 'female genres', such as melodrama and romantic comedy (cf. Stojanova, 2006: 95-114; Ostrowska, 2017: 233-247). Both promoted patriarchal gender models and were often openly sexist. Likewise, heritage cinema, which was highly popular at the time, nostalgically looking to a more or less distant past, appealed to an idealised national community and mobilised conservative gender discourse, as if to erase the communist concept of gender equality and its socio-economic aberrations. Ewa Mazierska considers this trend within Polish post-1989 cinema as part of a 'nostalgia business' manufactured to 'facilitate[s] and strengthen[s] nationalism, namely Catholicism, patriarchy, sexism, and elitism' (2007: 89). As if to counterbalance this conservative cinematic discourse, films subverting regressive and discriminatory gender politics began to emerge; yet their distribution was usually limited to film festivals and arthouse cinemas (Mazierska, 2007: 177-198). Although often addressed as made by 'reluctant feminists' (Iordanova, 2003: 123-125), postcommunist women's cinema slowly developed to question the dominant gender discourse (Mazierska, 2007: 177-198). Subsequently, Eastern European cinema opened up for more radical gender politics in that its representational system became more inclusive to encompass lesbianism, yet it was still embedded within nationalistic ideology (see for example Moss and Simić, 2011:271-283). Finally, the gradually emerging more diversified gender politics facilitated, or paralleled, unfolding other alternative subjectivities determined by ethnicity, class, or economic status. Most importantly, the Holocaust experience, a defining historical experience, especially for Poland and Hungary, had been revisited and opened up for critical scrutiny. Arguably, the first decade of the postcommunist period witnessed mobilisation of new subjectivities, yet their more substantial materialising occurred only in the new millennium.

It is tempting to map out cinematic production of the region during the first decade of communism along the fault line of regressive and progressive gender politics, associating it respectively with a pro and anti-feminist stance. However, I would argue that both popular as well as art cinema of the region responded to the political change of 1989 with more ambivalent approaches to gender issues than is frequently thought. There seems to be a significant, yet often non-articulated tension between narrative content and formal devices, the strain of which evoked conflicting aspects of Eastern European gender identity as it evolved during the period of political transition (cf. Ostrowska, 2017: 233-247). This transition proved to be a multi-directional and non-linear process entailing various divergences. To address these complexities, Michael Kennedy proposes the broad term of 'transition culture' which relates to a chain of interrelated changes between: plan and market, East and West, past and future, nationalism and globalism, suppression and freedom, dependency and responsibility, ideology and reason (2002: 186). Eastern European countries had to redefine their identity against all of these factors.

The concept of 'transition culture' negates the received wisdom that the year 1989 represented an epochal change for the region. To address the limitations of such an approach, Iveta Silova takes inspiration from JeanFrançois Lyotard's concept of the 'post-modern condition' (1984) and proposes the analogous concept of a 'postcommunist condition' (2010: 5) which implies various temporalities and polyvalent discourses mobilised before, during, and after the collapse of communism. ${ }^{1}$ Accordingly, gender discourse also developed along various,

\footnotetext{
${ }^{1}$ A similar approach is represented by Constantin Parvulesco and Claudiu Turcus, guest editors of a special issue of Eastern European Film Studies: "Most academic accounts in the field address 1989 as marking the fall of communism and the beginning of a transition period. These concepts have their worth, but are also problematic, as they bear the marks of cold war
} 
frequently contradictory, trajectories revealing uncertainty rather than confidence within feminist and anti-feminist ideological positions. Anikó Imre effectively addresses this ideological ambiguity in her discussion of postcommunist lesbianism and its ambivalent relationship with nationalism. As she explains:

For emerging lesbian groups in postcommunist countries, it is politically crucial not to engage in an essentialist opposition to heterosexuality, which would support the nation-state's own divisive strategies. What follows from this discussion of postcommunist lesbian ambivalence toward the nation is that it is difficult and problematic to issue feminist judgments without falling into multiple traps of ethnocentrism. It is not reliable to consider the work of East European feminists exclusively either in their specific national contexts or in a regional or global brushstroke. Only the simultaneous presence of all of these frameworks can yield enough specificity to unpeel layers of contradiction and make one understand how nationalism can prevent and enable lesbian identities at the same time. (2007: 161)

Imre's succinct point on polyvalent relationship of postcommunist lesbianism with various ideological discourses effectively demonstrates 'transition culture' and its effort to come to terms with the past and present political formations. Cultural production during this period, including cinema, demonstrates postcommunist 'gender uncertainty' in that it negotiates between conservative gender discourses and alternative modes of gender identification. Eastern European Cinema participated in 'transition culture' in its shift of production mode (from state to private forms of funding), stronger polarisation of popular and art cinema and implementation of a transnational production framework which would consequently re-define relationships between national and European cinema.

In this article, I will focus on several films made within Eastern Europe during the first decade of the postcommunist period that I believe represent 'gender uncertainty' and navigate between erstwhile ideologies and those emerging from the political changes marked by 1989. The temporal frame between 1989 and 1999 marks a critical point in 'transition cultures' in regards to gender discourses. Furthermore, selection of the first decade of the postcommunist period is also justified by aforementioned changes within film industry; as Joanna Rydzewska and I argue, the date of 2000 rather than 1989 marks the emergence of a new paradigm in Eastern European cinema:

the financial collapse of the Romanian film industry in 2000 and its subsequent industry developments (...) led to the rise of the Romanian New Wave after the year 2000 [and] can be used as a lens for understanding the changes in Eastern European cinema more generally. (Ostrowska and Rydzewska, 2018: 168)

The chosen film examples emerged from Polish, Hungarian, and Czecho/Slovak cinema, which remained relatively fertile post 1989 despite radically altered modes of production. None of these films offer an emancipatory project for women from the region, which reflects the socio-political reality of the period. However, they foreground gender subjectivity as dominant force in narrative development. In terms of cinematic form they do not fit the mode of transparent realism, yet they do not mobilise the feminist mode of 'counter cinema' either (see Johnston, 1999). Instead, they mark the initial moment of dis-attachment from the previous gender politics, and as such they perfectly embody 'transition (gender) culture'. Firstly, I will examine Ildikó Enyedi's My Twentieth Century (Az én XX. századom, Hungary/GDR/ Cuba, 1989) to argue that it destabilises normative models of femininity by means of both the narrative content and formal strategies. Then, I will take a close look at two films related to the heated 1990s debate concerning female reproductive rights: Dorota Kędzierzawska's Nothing (Nic, Poland, 1998) and Ildikó Szabó's, Cbild Murders (Gyerekgyilkosságok, Hungary, 1993). Whilst these films do not radically subvert patriarchal ideology, they denounce its discriminatory politics, especially effective on women that represent marginalised sectors of society. Finally, I will discuss The Garden (Zábrada, Slovakia, France, 1995) directed by Martin Šulík, to demonstrate how breaking with the code of realism facilitates the process of 'correction of patriarchy' (Skrodzka, 2012: 78). I will establish that these films significantly disrupt the national and thus patriarchal mode of address.

This shift from the national to the gendered mode of identification also marks a new point of encounter between Eastern European and Western feminism. The word 'encounter' seems especially important here as it implies a relationship based on a re-working of feminist ideas by both sides rather than more or less successful implementation of the ideas of Western feminism. During the time of the 'postcommunist condition', Eastern European gender discourse had to face not only patriarchal structures of state socialism and emerging neoliberal

anticommunism, neoliberal triumphalism and neo-colonialist bias, and assume linear, from-to, historical transformation. Consequently, this approach has overemphasised the importance of 1989 as a radical break, the legacy of the communist doctrine in the post-1989 present, the sheer rejection of the past as the main motor of development, politicised approaches to history, cultural pessimism, orientalising aspects, and the national character of cultural production." (2018: 1) 
capitalism but also hegemonic position of Western and 'global' feminism. ${ }^{2}$ Gender uncertainty and aesthetic modes of spectatorial distanciation employed in the films selected for the close analysis indicate this resistance and scepticism towards any singular mode of identification. The effect of spectatorial distanciation that originates from Brechtian concept of epic theatre and, more specifically, Verfremdungseffekt, results from employment of any cinematic device or technique that prevents the film spectator from identification with the action on the screen and the fictional reality (cf. Koutsourakis, 2018). As a result, the viewer is invited to take a critical attitude to the fictional reality and its ideological underpinnings. All the films that will be analysed in the following sections employ the effect of spectatorial distanciation, which in my opinion demonstrate distance from all ideological discourses on gender whether these are connected with Western feminism or patriarchal ideology of state socialism.

\section{'I AM NOT FEMINIST, BUT...', OR HOW EASTERN EUROPEAN WOMEN DID NOT WANT TO LOVE (WESTERN) FEMINISM}

In the 1990s, Eastern European countries became an arena for openly expressed anti-feminist sentiments frequently followed by significant limitation of women's political agency, especially their reproductive freedom. For example, in 1993 Poland introduced an abortion 'compromise bill' (one of Europe's strictest anti-abortion laws; see Fuszara, 1993). Abortion debates were also important for the project of German unification in 1990 (Funk, 1993). In Czechoslovakia, public discussion regarding reproductive freedom and women's participation in political life intensified after 1989; although it did not result in more restrictive abortion law, the cost of the procedure was significantly increased and, thus, its accessibility was reduced (Heitlinger, 1993). In Serbia, in 1990, The Law on Social Care for Children introduced bills that were intended to increase the birth rate, while issues of social care for families and children were visibly neglected (Milić, 1993: 113). Similar neglect of women's problems occurred in Hungary; in the beginning of the 1990s 'women's issues [were] not political issues' according to most of society (Adamik, 1993: 207). Finally, in Romania, in the first partially free parliamentary election, only 21 out of 397 seats were won by women, significantly fewer than in Ceausescu's days (Hausleitner, 1993). In general, for Eastern European women, the collapse of communism meant subjugation to patriarchal structures of power, whereas erstwhile 'gender equity' was often addressed as an unwelcome inheritance from doctrinal authoritarianism.

Implementation of conservative gender politics was considerably facilitated by anti-feminist sentiments that emerged in the region well before 1989. As Barbara Einhorn noted in 1993, many Eastern European women developed an 'allergy to feminism' (1993: 182). ${ }^{3}$ Another Western scholar, Jill M. Bystydzienski, recollects,

When I gave a lecture in 1986 at the University of Warsaw on the women's movement in the United States, I was assured by attentive women students that there was no need for a movement in Poland because women already had equality with men; in fact, too much equality as far as they were concerned! (2001: 503)

It is safe to say that across the whole region, feminists were stereotypically perceived as

"women who hate men and children, are sexually voracious, don't wear bras, and above all are very unhappy and are lesbians" (Adamik, 1993: 207). I personally recall that my female friends and colleagues would frequently use the disclaimer 'I am not a feminist, but...' to express a clearly feminist opinion. Most often, this casual form of votum separatum meant dissent not from feminist ideology per se, but, specifically, its Western model and its implementation. Eastern European women had a strong conviction that "Western feminists have distorted the situation of women in Eastern and Central Europe" (Tóth, 1993: 213). In consequence, Eastern European women who identified at that time with feminist movement still struggled over the definition of the term. As Elżbieta Kaczyńska admitted: "We tend to talk about our [Polish] feminism as what it's not-it's not like what the communists meant by gender equality or what it's like in the West—but we seldom state positively what Polish feminism is, or could be about" (quoted in Bystydzienski, 2001: 508). The first decade of the period of postcommunist is marked with ideological "uncertainty" over the term of feminism and the concept of gender equality. As Allaine Cerwonka explains, the terms of Western and Eastern feminism 'are not necessarily explicitly defined in the literature on the East-West divide in feminism, as it has been repeatedly phrased' (Cerwonka, 2008: 809). Instead of emergence of specific and well defined variant of Eastern European feminism, contestation of

\footnotetext{
2 As Katarzyna Marciniak comments, "the field of transnational feminist studies declares its "global scope" but its very idea of globality seems restrictive, circumventing Eastern Europe' (2008: 192).

${ }^{3}$ For a comprehensive discussion of the relationship between Eastern European and Western feminism see Rosalind March (2012) and Ewa Kraskowska (2012).
} 
various concepts of gender equality and women's activism surfaced. This reluctant and constantly fluctuating concept of feminism has mobilised equally vague forms anti-feminism in the region.

Although, for each country within the region, anti-feminist attitudes, sentiments and legal actions had their own specific determinants, all of these originated from communist legacy and its official 'gender equality' doctrine which had not been implemented in socio-political reality and ultimately resulted in the notorious 'double burden' (Funk, 1993:1); nevertheless, some emancipatory possibilities for women were opening during this period, however these were strictly limited within the system of patriarchal state socialisms. As Anikó Imre claims, anti-feminist sentiments displayed by individuals and collectives prior to the collapse of communism originated from the ideological appropriation of socialism by state socialist authoritarianism and 'the equally complex work of nationalism, which provided a matrix of automatic and primary self-identification' (Imre, 2017: 88). The national as opposed to the socialist (primarily associated with the Soviet oppression) functioned as the primary identification framework for Eastern European societies. Thus, in oppressive totalitarian regimes, gender was marginalised in identity projects or embedded within a socialist framework intrinsically complicit with the doctrine of state socialism, and/or the nationalist discourse that was resistant to the former.

However, it needs to be emphasised that Eastern European antifeminism emerged well before the collapse of communism. Despite the official 'gender equity' doctrine, many Eastern European countries the 1980s witnessed an upsurge of conservative gender discourse. A growing neo-conservatism surfaced in Bulgaria, Romania, former Yugoslavia (some attempts were made to restrict reproductive rights in Serbia), the ex-GDR (several changes were made in women's employment regulations), Czechoslovakia, Hungary, and Poland (Funk, 1993:4). This conservative gender policy in the 1980s and 1990s paradoxically coincided with an anti-feminist backlash in the Western world. The leading Polish feminist scholar Agnieszka Graff claims that Eastern European societies 'skipped the radical 1960s and got a double dose of the conservative 1980s' (2007: 147). She further explains, "Polish gender politics do not fit the Anglo-American chronology (...) our chronology is different" as Polish feminism emerged 'between the waves', that is between the second and third wave feminism (2007: 142). Imre points out another 'in-betweenism' of Eastern European feminism that 'of being forced to choose between first and third-world identifications' (2007: 153). This 'in-betweenness' illuminates the phenomenon of anti-feminism after the collapse of communism, the transitional period per se. As Graff explains,

For despite not having had much of a second wave feminism, we Polish women did experience a backlash. In fact, many of us internalized its message before discovering feminism. (2007: 144)

On the top of this, the collapse of communism mobilised nationalist sentiments in all the countries of the former Eastern Bloc and, in consequence, a retreat to conservative models of femininity occurred under the disguise of discarding communist legacy.

Eastern European intellectuals and artists contributed to the embedding of and marginalisation of gender discourse within national discourse. Importantly, many Eastern European female filmmakers whose work was frequently focused on gender issues habitually refuted any overt link with feminism. As Dina Iordanova reported:

leading female directors from the region have distanced themselves from 'feminism', a situation that leaves us facing the curious phenomenon of clearly committed feminist film-makers who are nonetheless reluctant to be seen as such. (2003: 123)

Imre explains that this anti-feminist stance of Eastern European female filmmakers did not necessarily originate from their 'inherent' opposition towards it but rather from the Western perception that their films were 'forced into a gendered box specially fabricated for "East European" or "national" auteurs' (Imre, 2017: 88). Consequently, Eastern European cinema developed a uniquely stable and effective 'script of male universalist nationalism' (Imre, 2017: 90). Eastern European art cinema 'nationalised' the potentially subversive practices of non-realistic and avant-garde cinema, 'leaving little room for subnational identifications' (Imre, 2017: 91). Factors such as gender, ethnicity, and class had been marginalised, if not entirely erased from the socialist identity project in a classless and homogenous society ruled by proletariat. Eastern European cinema of the first decade of communism did not bring a significant change in terms of plurality of subject positions addressed within fictional realities. However, several filmmakers decided to reconsider gender identities and locate these in new ideological and aesthetic contexts. The films I will be discussing in the following sections of the article foreground the 'subnational identifications' hereby opening up for polyphony of ideological discourses and modes of spectatorial address.

\section{MYTWENTIETH CENTUR Y: FEMINIST MASQUERADES AND CINEMATIC GAMES}

Ildikó Enyedi’s film My Twentieth Century (Az én XX. századom, Hungary/GDR/ Cuba, 1989) is an early and intriguing example of subverting singular gender discourse whether constructed from patriarchal or Western 
feminism positions. As Imre claims, the film also provides useful material from which to discuss 'the 'translatability' of feminism in general and feminist film theory in particular into Eastern European terms' (2003: 177). The film, whose release coincided with the collapse of communism, tells the story of twin-sisters, Lili and Dóra, ${ }^{4}$ orphaned by their single mother and adopted by two families. The proper action of the film begins when they both travel on the same train not being aware of the fact. Although played by the same Polish actor, Dorota Segda, they look very different and embody two radically opposed concepts of femininity. One is an active member of the suffragette movement, whereas the other is a pampered courtesan, who lives off men. On one hand, their personas embody patriarchal concepts of femininity as embodied by the opposing figures of the 'virgin' and the 'whore'; on the other hand, this contrast is so ostentatious that their images appear to be a self-reflexive rendition of ideological and cultural clichés. Imre calls it 'gendered excess' (2003: 189) and comments:

On the one hand, Lili and Dóra do correspond to the mother-whore dichotomy (...). On the other hand, their performances of femininity expose the dichotomy as a vehicle of essentialist discursive control over women's sexualities. (2003: 194-195)

Importantly, the ending of the film ultimately ambiguates the initial binary model of femininity as the sisters finally meet in a mirrored labyrinth in which multiplied reflections visually annihilate their previously well defined singularities and attendant cultural values and meanings.

My Twentieth Century transposes the non-singular female identity into spatial trajectories and non-linear temporalities which are at odds with hegemonic national history. The narrative begins on New Year's Eve of 1880 in Menlo Park, New Jersey, where Thomas Edison demonstrates his new invention of electric light. The '1880' intertitle may suggest a realistic historical mode of narrative ${ }^{6}$, however it is a history of subnational scientific invention rather than recreation of specific national (Hungarian) past. The realistic mode of representation is additionally disrupted when Edison looks at the sky and hears two female voices coming from the two brighter blinking stars as they ask him to look at Budapest, Hungary, where the twins have just been born. The playful and giggling tone of their voices suggests that the journey to come will be a playful game rather than an enlightening experience. $Z$, the male protagonist, who engages erotically with both sisters, is a mocking version of the traditional figure of explorer, scientist, and traveller who transmit masculine imperialism. In one scene, $Z$ meets an Englishman to whom he introduces himself as a Hungarian. His new acquaintance expresses disbelief stating that countries like Hungary, Bohemia and Romania do not actually exist as they were merely imagined by Shakespeare. Arguably, during his travels, $\mathrm{Z}$ does not learn much about himself as either a man or a Hungarian; indeed, the opposite happens as his identity melts and disperses. As Catherine Portugese concludes, My Twentieth Century offers a criticism of both patriarchy and nationalism (2007: 528). ${ }^{7}$

The sisters also embark on various journeys, yet these are not 'learning' experiences either. Their travels do not develop into rational and well ordered trajectories marked by clearly defined points of departure and arrival. They seem to be more of a permanent condition of existence. The first scene featuring the grown up twins takes place on the Orient Express. Dóra is travelling in a first class compartment, whereas Lili is squeezed into third class seats as she carefully protects the bomb she is delivering to her comrades. Later, the sisters both traverse many places; however, all of these are public spaces of streets, squares, trains, lecture halls, restaurants, bars, etc. None could be identified as domestic space, traditionally conceived as a women's domain. Importantly, the sisters are not in a search of 'home'; perhaps they do not believe in the saying 'there is no place like home'. Throughout the film they remain 'displaced', yet this literal and figurative 'homelessness' is neither experienced as 'exile' nor 'liberation', thus, the symbolic value of 'home' ceases. If there is no home, there is no homeland. Dóra and Lili appear as female nomads. Yet their trajectories are neither singular nor linear and they do not always mobilise emancipatory

\footnotetext{
${ }^{4}$ Interestingly, a similar sisterhood duo is featured in the film by Polish female filmmaker Barbara Sass-Zdort, Spiderwomen (Pajeczarki, 1993). The motif of doubles is also prominently used by Krzysztof Kieślowski in Double Life of Veronique, which features twin women living separate lives in Poland and France who are ignorant of each other's existence.

${ }^{5}$ Catherine Portugese emphasises the importance of using the strategies of irony and paradox which are staples of artistic representation in Eastern European cultures (2007: 528).

${ }^{6}$ In her article, Imre notes, that although, generically, it is a period film, Edison's discoveries are not national but universal 'historical' events, though the film depicts them from 'a markedly personal, fictive, and explicitly female angle' (2003: 191).

${ }^{7}$ Catherine Portugese's analysis can be also be perceived as an effort to de-nationalise the film's content via its psychoanalytical reading and emphasis on the issue of gendered desire. During the period of state socialism, Eastern European societies were as sceptical towards feminism as they were regarding psychoanalysis. I still remember how Polish film scholars were amused, to say the least, by the psychoanalytical interpretation of the flagship of Polish socialist realist cinema An Adventure at Marienstadt (Przygoda na Mariensztacie, L. Buczkowski, 1954) offered by Wiesław Godzic in his book about psychoanalysis and cinema published in 1991. I believe that the book itself was an attempt to 'de-nationalise' critical discourse on Polish cinema, yet, at that time, the response was one of amusement, if not open derision, based on the tacit assumption that psychoanalysis 'does not fit' with Polish realities.
} 
potential. During one of her trips, Lili attends a lecture delivered by Otto Weininger, an infamous advocate of gender inequality, during which she is subjected to humiliation and discrimination disguised as academic discourse. ${ }^{8}$ Clearly, journeys are not always liberating and sometimes they may expose women to social ostracism and condemnation. Arguably, My Twentieth Century offers a gendered motif of journey that cannot be identified as either a negative or positive experience and thus it cannot transmit a singular ideological system.

Most importantly, the narrative of My Twentieth Century does not develop the national scenario that would transform female character into a national allegory (cf. Goscilo, 1997). Although Imre claims that Dóra and Lili can be seen as national allegories demonstrating two different attitudes towards state socialism in Hungary in the 1960s and 1970s, respectively, both cynical exploitation and idealistic resistance, she also claims that this interpretive potential is overshadowed by the prominence of the gender theme (2003: 197). In turn, Skrodzka advocates interpretation of the two women as 'global' allegories of West and East, with Dóra representing faith in capitalism, whereas Lili believing in the ideals of Communist revolution; later, she also argues that Lili represents 'the collective body of feminised East Central Europe' (2012: 130, 132). I would argue that the ending of the film, specifically Z's final confusion about the 'multiplied' female subject, prevents the emergence of female national/global allegories. With the two females mirroring each other, their identity perpetually fluctuates and, thus, cannot be embedded within a stable national/or global narrative. Imre usefully concludes,

the film's simultaneous flirting with allegory and refusal to allow the nation to appropriate its entire allegorical potential, and its flirting with history but simultaneous refusal to allow Hungarian history to be its ultimate referent, do produce a double, self-subverting coherence. (2003: 200).

Instead of a radical act of textual 'erasure' of female national allegories, Enyedi offers their mocking or merely playful variants.

My Twentieth Century also 'flirts' with both patriarchal and feminist concepts of gender. Both Dóra and Lili use excessive means to identify themselves as respectively 'suffragette' and 'courtesan'. Thus, femininity as performed by the sisters is always a masquerade adjusted every time to specific spatio-temporalities. As the stars say at the beginning of the film: 'Look at Budapest' they imply that things there are different to New Jersey in the States. Hungary was not invented by Shakespeare after all! It does actually exist, as do Eastern European women replete with their own stories which are very different to those told in America's New Jersey.

To conclude, My Twentieth Century employs patriarchal gender stereotypes in excessive fashion that denaturalises their ideological content. The self-reflexive play with these stereotypes foreshadows contradictory gender discourse to emerge after 1989. Most importantly, the film does not offer a clear narrative resolution and none of the sisters is presented as either victorious or defeated which parallels the co-existent and often contradictory gender discourses during the first decade of postcommunism.

\section{PREGNANT BODIES AND ABJECT SPACES}

In this section of the article, I will be discussing how postcommunist cultural production addressed the issue of women's reproductive rights that became an issue of heated political debate in much of postcommunist Eastern Europe. Cinema has vaguely responded to this issue in that it avoided articulating clear political stance and, instead, transformed it into more universal 'moral tales'. This ideological ambivalence testifies to ideological struggle over the concept of feminism and its political agenda. The most significant and well known film on the subject of the restrictive abortion law implemented by the government of Nicolae Ceauşescu, Four Months, Three Weeks, and Two Days (4 luni, 3 saptamâni si 2 zile, Cristian Mungiu) was made in Romania in 2007, thus, almost twenty years after the political turn. Polish cinema of the 1990s engaged with the problem of unwanted pregnancy and prospective abortion relatively often (e.g. Decalogue 2 (Krzysztof Kieślowski, 1990), I Look at You, Mary (Patrze na Ciebie, Marysiu, 1999), Track-W ay (Torowisko, Urszula Urbaniak, 1999)) 9; however, only one film, made by female director Dorota Kędzierzawska, Nothing (Nic, 1998) makes this its central theme. Despite this, in her public statements, Kędzierzawska avoided being linked with a feminist agenda. Mazierska calls Kędzierzawska an 'ambivalent feminist' (2006: 205-220), which, as mentioned, was not uncommon among Eastern European female filmmakers

\footnotetext{
${ }^{8}$ Portugese also argues that the character of Otto Weininger is 'a caricature of a certain kind of pathological patriarchal masculinity, fighting for survival whilst unconsciously and uncontrollably engaged in a dangerously undermining masquerade of his own' (2007: 535).

${ }^{9}$ In Torowisko (Track-Way, 1999, Urszula Urbaniak) pregnancy is a result of the rape of one of the female protagonists. In $I$ Look at You, Mary, 1999, Patrze na Ciebie Marysiu, Lukasz Barczyk Mary's pregnancy causes a crisis as her partner does not want to be a father. Finally, in Decalogue 2 - a young woman cannot decide whether to continue with her pregnancy or opt for an abortion.
} 
at that time; although they clearly engaged with women's issues from a feminist perspective, they refused to adopt the identification ${ }^{10}$.

Notbing tells the story of a young woman, Hela, who lives in poverty with her husband and three small children. When she becomes pregnant again, she tries to get an abortion, yet the health service denies this to her, clearly following the newly implemented abortion law in Poland. Her husband suspects the pregnancy and threatens to kill her if another 'bastard' is born into the family. She tries to find support from the church, yet in vain. After giving birth at home on New Year's Eve, she kills the baby and buries it in a secluded place. She then leaves home, yet is soon caught by the police and consequently subjected to trial. When asked if she has anything to raise in her defence, she says the titular 'nothing'. The story itself may suggest that the film is a critical depiction of the sociopolitical realities of Polish women in the 1990s, yet the cinematic rendition of the theme and the story are as far from cinematic realism as can be imagined.

In Nic, Kędzierzawska clearly believes, to use André Bazin's distinction, in 'image' rather than 'reality' (1967: 24). Mazierska succinctly notes: 'it is impossible to watch the film without being aware of its form' (2006: 219). Stylised mise-en-scène and cinematography are similar to the aesthetic design of her earlier films Devils, Devils (Diably, diabty, 1991) and Crows (Wrony, 1994). This stylistic consistency locates the film within the framework of Eastern European auteur cinema and its tradition of 'universal humanism'. Although, Kędzierzawska admitted that her script had been inspired by reportage published by a leftist Polish newspaper Gazeta Wyborcza, concerning a woman who killed her newly born child after being denied an abortion, she vehemently contested that her film was a political statement. As Mazierska reports,

Off-screen Kędzierzawska played down any suggestions that her film contains criticism of the current abortion law or of the Catholic Church, and that it promotes women's rights. (2006: 218)

It can be argued that the filmmaker employed visual stylisation, fragmented narrative, and ambiguous characterisation to 'universalise' the gendered topic and transform it into a symbolic tale of loneliness, helplessness, and moral dilemma.

Due to its topic and distinct aesthetic design, Kędzierzawska's Nothing can be compared to the Hungarian film, also made by a female director, Ildikó Szabó, Child Murders (Gyerekgyilkosságok, 1993). The film tells the story of 12year-old Zsolt whose mother moved to the West, leaving him in Budapest with his sick alcoholic grandmother. One day he meets a pregnant Roma girl ${ }^{11}$, who also lives a solitary life, in an abandoned dilapidated train wagon. After she has a miscarriage, he helps her to discard the dead foetus. When they throw it away into the Danube River, a neighbourhood girl witnesses it. She reports this to the police, accusing the couple of infanticide. The Roma girl consequently commits suicide, whereas Zsolt kills the local girl out of revenge. In her review of the film Caryn James enquires: "When he takes violent action, is he acting out of some innate immorality? Or is he another victim of a society that abandoned him?” (1994: 17). Indeed, similarly to Kędzierzawska's Nothing, Szabó's film can also be seen as both a universal moral debate on the nature of evil and an examination of socio-political issues of marginalisation and exclusion in Hungary during the early 1990s. Abandoned by his mother who took advantage of postcommunist freedom by travelling to the West, Zsolt represents the negative consequences of Eastern Bloc liberation. The Roma girl personifies an ethnic group traditionally ostracised and marginalised within Eastern European nation states. Her pregnancy, most likely unplanned or perhaps even the result of sexual abuse, which ends with a miscarriage, indicates how certain groups of women, coming from underprivileged social strata (including Hela from Kędzierzawska's film), are deprived of both care and support, a situation that entails grave mental, emotional, and physical consequences.

Both films present pregnancy as a negative experience, yet their aesthetic excess obscures the social and the political aspects behind the existential and the moral angles. As Polish feminist, Kazimiera Szczuka, states, in Kędzierzawska's film 'everything was hidden behind beautiful and aestheticised frames' (2004: 225; see also Podsiadło, 2009: 87). This aesthetic veneer could be paralleled with the fact that in postcommunist Poland, women were not only unable to make their own decisions regarding abortion, but they were not allowed to address the experience from a woman's perspective because, as Szczuka claims, abortion itself had been appropriated by

\footnotetext{
${ }^{10}$ In her survey of Polish films examining the issue of abortion, a Polish sociologist Ewelina Wejbert-Wasiewicz comments that the feminist declaration made by Kędzierzawska would negatively affect the viewers' attitude to the film (2018: 264). Admittedly, I was rather shocked after reading this statement without any critical comment, especially as the article was published in 2018, thus, almost twenty years after the film's release, when feminist discourse was approached far differently by Polish society than at that time the film was made.

${ }^{11}$ Interestingly, Kędzierzawska's acclaimed debut Devils, Devils (1991) features the characters of Roma people, examining the difficult and often biased relationships experienced by this ethnic group within the rest of Polish society; for detailed analysis of the film see; Mazierska 2006b: 206-212).
} 
rightist pro-life ideology (2004). By the same token, it could be argued that art cinemas code of 'universal' humanism has appropriated women's experience of unwanted pregnancy and infanticide committed out of fear and despair. Child Murders seems to perform an analogous aesthetic and ideological appropriation as the pregnancy of a Roma girl is presented from the perspective of a Hungarian boy who through his ethnic and gender identity is still related to the hegemonic society. His character is a focal point of the film's narrative and spectatorial identification.

Notwithstanding the ideological ambivalence of aesthetic excess of both films, I would argue that Kędzierzawska and Szabó use this formal strategy not to evade engagement with socio-political issues, but rather to create an affective equivalent of 'invisibility' of these issues within public discourses. The most conspicuous similarity between Nothing and Child Murders is their use of colour and lighting diminishing the referential aspect of the cinematic image. Kędzierzawska's film employs a very limited colour palette of shades of brown and grey, whereas Szabó uses black-and-white film stock. The limited and often desaturated colours eliminate contrast between figures and their background, visually suggesting the impossibility of emergent individual subjectivity. Both films use low-key lighting, especially in the interior scenes. This leaves the characters' faces in darkness, producing an effect of emotional and psychological opacity. As Agnieszka Zielińska comments on Nothing:

the actual physicality of the body is highly abstracted. This mode of visual narration underscores the idea that such personal tragedies are often cloaked within multiple layers of inarticulate suggestion that distort their true meaning. (2010: 178)

Szabó's film also implements aesthetic strategies that reduce the visibility of female bodies. The 'invisibility' of women and their bodies in both films incapacitates the voyeuristic male gaze; however, it may also indicate the phenomenon of 'vanishing woman' from postcommunist public discourse as described by Graff. The feminist scholar claims that public discourse on abortion in post-1986 Poland articulated an exclusively masculine position. In consequence, female experience was appropriated by patriarchal language, replacing the term 'abortion' with the phrase 'murder of an unborn child'. Importantly, she notes, the word 'woman' was almost entirely absent from the abortion debate as it focused exclusively on 'conceived child'. As the word 'woman' vanished from discursive language, women also vanished from public life as political subjects (Graff, 2001: 111-113).

Kędzierzawska and Szabó’s films, I argue, employ formal strategies, specifically visual opacity, to address this 'silencing' of women in public life and distant the viewers to provoke them to take a critical stance towards the problem. Mise-en-scène and cinematography employed in the scenes of birth giving in both Nothing and Child Murders do not only render it 'invisible' but also relegate it to the realm of the abject as proposed by Julia Kristeva (1982). Kędzierzawska locates the birth scene in the bathroom, a space designated for cleansing and excretion. This is the place where the body is rendered clean and proper. Having Hela give birth in the bathroom defines her pregnant body as an abject body that needs to be cleansed and purified (from the foetus?). Moreover, the scene is filmed from the perspective of Hela's husband who observes it through the frosted glass of the bathroom door. The image is distorted, fragmented, and blurred. A close up shows Hela's hand squeezed on a chair, yet her face is not presented even momentarily. I would argue that for both Hela and her husband the pregnant body is an abject body; she chooses the symbolic space of a bathroom in which to give birth, whereas her husband silently accepts this and decides to remain outside of this 'abject' space. In his elaboration of Kristeva's concept of the abject, Nick Mansfield notes: "the abject impulse is inalienably connected with the feminine, specifically the maternal" (2000: 88). The permeability of the pregnant body epitomises the ambiguity of any demarcation line and border and, thereby, of any symbolic order. The cinematography and mise-en-scène in Kędzierzawska's film conspicuously demonstrate how the masculine subject defines a pregnant body as an abject body and how the female subject internalises it.

Child Murders also features a scene of birth in the abject space of an abandoned railcar wagon. The space here is arbitrary and opposes any sense of social order. It serves for everything from sleeping, eating and socialising, to cleansing and excretion. It epitomises an absence of borders and structure. The Roma girl's miscarriage additionally blurs the border between life and death. A dead foetus merges her experience of motherhood and mourning and, thus, is a perfect example of the abject. The girl also epitomises the abject due to her ethnic identity (she is both, Hungarian and Roma), her age (she is a girl, yet her pregnancy shifts her towards mature femininity), and even her gender identity (her short hair and well-defined facial features make her gender somehow fluid). Zsolt's attitude to her confirms this ambiguity, as he seems to treat her as both, a surrogate mother who will sooth and protect him, and a partner who needs his protection. The girl, perceived as an abject being, endangers the social order established within the local community. Thus, the neighbourhood girl who always dons white clothes and seems to be the epitome of innocence and purity (or a clean and proper body to use Kristeva's concepts), undertakes the task of eliminating human 'dirt' from their environment. She reports the alleged infanticide to the police. The Roma girl's suicide testifies to the internalisation and acceptance of her being the abject (not unlike Hela from Nothing), which needs to be ultimately annihilated. The female protagonists of Notbing and Child Murders reveal the 
dirty underbelly of patriarchal protectiveness toward women and motherhood. They reveal the fact that women actually function as society's 'pariahs' (cf. Szczuka, 2010: 204). The films' formal devices can be seen as a symptomatic revelation of this social and cultural stigmatisation and invisibility.

Notbing and Child Murders evokes the 'invisibility' of female characters due to the effect of the excess of setting and props and the compositional pattern of putting various objects in the foreground in order to obstruct the camera's view of the characters. Zielińska argues that Kędzierzawska 'creates a space that is deprived of any referential cues towards a specific setting, but very dense in terms of symbolism and metaphysics' (2010: 177). Likewise, in Child Murders space is symbolic rather than realistic. The camera work intensifies this opacity of space. The characters are often filmed from the rear or from a long distance. If there are close-ups, they are rarely, if ever, reaction shots that provide the viewer with insight into the characters' emotional and psychological life. Furthermore, in both films there is an abundance of high angle shots; in Nothing this takes place in the courtyard of the apartment building where Hela lives with her family, whereas in Child Murderer this is mostly the bridge over the Danube River, the site of the children's' 'murder'. These prolonged and recurrent images always emptied of narrative content (nothing story-wise happens in these shots) convey feelings of entrapment and downfall. The lack of socio-political details of the female protagonists' lives is compensated with an intense affective experience of these realities.

To conclude, opacity of visual codes and narrative fragmentation employed by both films signal the erosion of traditional (patriarchal) forms of cinematic expression and their inability to present the marginalisation, exclusion, and objectification of women. Most importantly, non-realist codes of representation open up subnational modes of address mobilising factors such as gender, age, and ethnicity.

\section{THE GARDEN: MASCULINITY IN CRISIS AND DEMYSTIFIED FEMININITY}

The Slovak film The Garden (Zábrada, 1995) directed by Martin Šulík plays with the traditional concept of femininity as connected with nature and acting as a saving or rejuvenating force. As Aga Skrodzka notes, it offers a 'corrective vision of patriarchy' (2012: 78). Jakub, the protagonist of the film, epitomises 'masculinity in crisis'. A teacher, currently on a long-term leave due to unspecified health issues, he lives with his father, a dressmaker. The latter is a nice chubby guy whose demeanour makes him anything but an embodiment of virile masculinity. The first scene of the film makes it clear that neither of these men is able to fulfil the social expectations imposed on their gender. The viewer observes the father fitting a shirt for Tereza, a female client, evidently taking a semi-erotic pleasure from the process. The woman slowly undresses leaving on only her bra; then the father helps her don the shirt, touching it sensuously. Jakub, wearing his pyjamas sits upon his bed witnessing the silent spectacle performed by his father and the client. When the father works on some necessary adjustments (which would demand one more fitting), the woman enters Jakub's bedroom, closes the door, takes off her bra, and invites him to explore her body. For a while he stays passive, but finally he succumbs to Tereza's sexual advances, then his father opens the door and reprimands the couple for their 'filthy' behaviour. That evening, the father requests for Jakub to leave and go to the family countryside cottage, sell it and then buy an apartment for himself. The son agrees to this and the following day drives to the place his father once left to embrace an easier and more prosperous life in the city.

Jakub's decision to go to the family estate could be seen as his effort to reconnect with his patrimonial roots and possibly revive his masculine agency. However, as Skrodzka notices,

What would seem, on the surface, to be the seat of patriarchal legacy, the family estate, in Šulík's film, turns out to be a heap of rubbish barely withstanding the forces of nature that have been hard at work consuming the vestiges of former glory. (2012: 81)

In the scene depicting Jakub's arrival at the estate, the film self-ironically plays with themes of mystery and revelation. Jakub is unable to open the gate so he decides to climb over it, yet once he mounts it, it somehow mysteriously opens (a visualisation of the saying 'push at open doors'); then upon his walk to the house, he accidently falls into his grandfather's cesspool (a grotesque liminal point) soiling his clothing, a symbol of his bond with urban life and civilisation. After spending the night in a bed which has been nested in by some local birds, he changes into shapeless (and 'timeless' for that matter) pants and shirt, which denote his belonging to the space of the mythical 'garden' visibly separated from the spatio-temporality of modernity. Clearly, he is ready to be 'reborn' and soon a young woman, the 'Miraculous Virgin', enters the scene, 'as a potential catalyst of the change to come' (Gindl-Tatárová, 2004: 246).

Helena, the 'Miraculous Virgin', contrasts with Tereza, who is an embodiment of rampant and predatory female sexuality. Tereza is visibly older than Jakub, imbuing their affair with some incestuous innuendo. Her aggressive seductiveness manifests when she visits Jakub at the cottage and attempts to use her sexuality to persuade him to return with her to the city. He initially accedes and even changes his clothes back to his former 'city' garb, yet 
eventually he abandons her at the bus stop, refusing to go back to his 'old' life. Tereza's excessive characterisation embodies the archetypal 'whore' whose unsatiated sexual appetite destroys men and renders them unable to grow and acquire subjective agency. According to the patriarchal mythical scenario, this destructive female agency needs to be annihilated and replaced with the healing presence of a pure and innocent 'virgin'. The film mobilises the traditional binary model of femininity as defined by the male subject only to later dismantle it.

Like My Twentieth Century, The Garden uses 'gender excess' to characterise the two female characters only to ultimately deconstruct and dismantle patriarchal ideology. The film features several episodes involving Jakub and Helena that conspicuously and playfully subvert the archetypal scenario of a man being saved by a woman (by virtue of her selfless and pure love). On the first day of Jakub's stay at the cottage, a dog unexpectedly attacks him. In panic, Jakub climbs an apple tree to escape the invading 'beast'. When he notices a young girl lazily strolling across the garden, he asks her to remove the dog. She obediently follows his request, yet to achieve this she performs a rather strange trick: she inserts an apple into her mouth and then bends forward slightly, adopting a pose which entices the dog to take the fruit. The dog jumps up, bites the apple from her mouth and runs away. Jakub looks at her in astonishment as if he is witnessing an act of witchcraft. To check whether she is an 'earthly' female creature, he looks into her décolleté. She scolds him for this and subsequently departs, remaining as inscrutable as she was when she first entered his field of view. Her intimate and mysterious bonds with the natural world make her a signifier of 'nurturing nature' and therefore a potential source of renewal for the male subject. However, this episode also demystifies her relationship with the invading dog as purely accidental and based not on any kind of spiritual communication but on an ad hoc trick. Ultimately, her rescue of Jakub is anything but the benevolent act of saving a tormented soul.

Helena visits Jakub's house whenever she wishes. According to Skrodzka, she

offers her help simply by being there and enacting gestures that she knows will help, all without uttering a single unnecessary word, bringing to mind the feminist epistemology of embodied knowledge. (2012: 82)

When Helena stops her visits, Jakub is worried by this and decides to look for her. He learns from her alcoholic mother that the girl is sick and unconscious. He takes her to his house to care for her, perhaps in hope that he will rescue the 'sleeping beauty' symbolically validating his masculinity. Alas, his efforts are in vain until his cat Behemot unexpectedly appears at the cottage and wakes Helena (who acts as if nothing has happened) with its 'gaze'. In the episode, Jakub is a passive witness to female transformation triggered by non-human agency, whereas the feminine resists its inscription within the fairy-tale scenario of the prince rescuing a virginal sleeping beauty.

The ending of the film 'corrects patriarchy' in a doubly effective way as it occurs at both a narrative and formal level. The scene features Jakub sitting together with his father on the bench next to the cottage, whereas, oblivious to the men, Helena walks around the garden. At some point, she lies down on the table that stands opposite to the two men as they talk to each other. For a while, she bends her neck and hangs her head over the side of the table. Suddenly her body, much to the men's astonishment, starts to levitate. After a while, the father says: 'At last everything is as it should be'. The scene shows two men, a father and son, and a young woman whose levitating body epitomises her freedom. They look at her and this double male gaze potentially transforms Helena into an 'object-to-be-looked-at' as conceptualised by Laura Mulvey in her seminal essay (1975). However, camera work and mise-en-scène destroy the mechanism of 'visual pleasure' directed at the male heterosexual viewer. Firstly, the scene presents Helena in long shots with a noticeable absence of close-ups, which are frequently used to fragment and fetishise the female body. Secondly, Helena's body occupies a position, which facilitates the male voyeuristic gaze; however, it simultaneously resists it through an act of levitation. Admittedly, the last scene mobilises the politics of gaze typical of the patriarchal system of representation, however it instantly subverts it through a direct address of voyeuristic pleasure and symbolic transcendence of the female bodily object. Helena's liberated body replaces the Logos, a foundational principle of patriarchy.

To conclude, The Garden addresses the postcommunist crisis of patriarchal models of masculinity and femininity, yet without replacing these with alternative modes of subjectivity. Therefore, it could be argued that the film figuratively addresses the postcommunist process of fluctuation of gender identities. The non-realistic modes of cinematic representation reinforce the process of erosion of hegemonic ideologies as represented in the fictional reality.

\section{CONCLUSION}

Although made in various Eastern European countries and different times, all the examined films induce spectatorial distanciation. In My Twentieth Century, this results from fragmented narrative and excessive characterisation, especially in terms of feminine stereotypes. In Notbing and Child Murders, it arises from episodic 
narrative and visual excess which together immobilise the flow of narrative events. Finally, in The Garden it occurs via the narrative being divided into chapters with poetic titles and introduction of the characters as symbolic figures. The spectatorial distanciation parallels disconnection as experienced by Eastern European societies, especially women, after the collapse of communism in relation to their past and uncertainty about the future. The aftermath of the1989 revolutions witnessed the collision of various ideological, political, and social formations. Their often turbulent co-existence disturbed any singular mode of national or gender identification. The analysed films ambiguously engage with these conflicted concepts of gender and, thereby, their portrayals of women resist simple identification as 'progressive' or 'regressive'. Instead, they present femininity in a state of constant flux, which is conveyed by collage-like imagery and fragmented narrative. These modernist aesthetic strategies of spectatorial distanciation may also indicate Eastern European feminism being estranged within the context of global feminism.

\section{REFERENCES}

Adamik, M. (1993). Feminism and Hungary, in N. Funk and M. Mueller (eds), Gender Politics and Post-Communism: Reflections from Eastern Europe and the Former Soviet Union (pp. 207-212). London: Routledge.

Bazin, A. (1967). What is Cinema?, transl. H. Gray. Berkeley: University of California Press.

Bystydzienski J. M. (2001). The feminist movement in Poland: Why so slow? Women's Studies International Forum. 24(5), 501-511.

Chowaniec, U. and U. Phillips, (2012). Women's Voices and Feminism in Polish Cultural Memory. Newcastle upon Tyne, UK: Cambridge Scholars Publishing.

Cerwonka, A. (2008). Traveling feminist thought: Difference and transculturation in Central and Eastern European feminism. Signs: Journal of Women in Culture and Society, 33(4), 809-832.

Daković, N. (2010). Love, magic, and life: Gypsies in Yugoslav cinema, in J. Neubauer and M. Cornis-Pope (eds), History of the Literary Cultures of East-Central Europe: Junctures and disjunctures in the 19th and 20th centuries (pp. 391401). Amsterdam, Netherlands: John Benjamins Publishing Co.

Drakulić, S. (1993). Women and the new democracy in the former Yugoslavia, in N. Funk and M. Mueller (eds), Gender Politics and Post-Communism: Reflections from Eastern Europe and the former Soviet Union (pp.123130). London: Routledge.

Einhorn, B. (1993). Cinderella goes to Market: Citizenship, gender, and women's movements in East Central Europe. London: Verso.

Filipowicz, H. (2001). Taboo topics in Polish and Polish/Jewish Cultural Studies. The Journal of the International Institute, 9(1), 3-8.

Fimyar, O. (2011). A manifesto of a postcommunist, poststructuralist researcher. Post-Viva Voce reflections. European Education, 43(2), 74-97.

Forrester, S. et al. (eds) (2004). Over the Wall/After the Fall: post-communist cultures through an East-West gaze. Bloomington: Indiana University Press.

Frunz, M. and Vcrescu, T. E. (eds). (2004). Gender and the (Post) 'East'/ 'West' Divide. Cluj-Napoca: Limes.

Funk, N. (1993). Abortion and German unification, in N. Funk and M. Mueller (eds), Gender Politics and PostCommunism: Reflections from Eastern Europe and the former Soviet Union (pp. 194-200). London: Routledge.

Fuszara, M. (1993). Abortion and the formation of the public sphere in Poland, in N. Funk and M. Mueller (eds), Gender Politics and Post-Communism: Reflections from Eastern Europe and the former Soviet Union (pp. 241253). London: Routledge.

Godzic, W. (1991). Film i psychoanaliza: problem widza. Kraków: Wydawnictwo Uniwersytetu Jagiellońskiego.

Goscilo, H. (1997). Dehexing Sex, Russian Womanhood During and After Glasnost. Ann Arbor, MA: University of Michigan Press.

Graff, A. (2007). A different chronology: Reflections on feminism in contemporary Poland, in S. Gillis, G. Howie and R. Munford (eds). Third Wave Feminism: A critical exploration (pp. 142-155). Expanded 2nd ed. Basingstoke, Hampshire, UK: Palgrave Macmillan.

Graff, A. (2001). Świat bez kobiet. Pté́ w polskim s̀yciu publicznym. Warszawa: W.A.B.

Hausleitner, M. (1993). Women in Romania: Before and after the collapse, in N. Funk and M. Mueller (eds), Gender Politics and Post-Communism: Reflections from Eastern Europe and the former Soviet Union (pp. 53-61). London: Routledge.

Heitlinger, A. (1993). The impact of the transition from communism on the status of women in the Czech and Slovak republics, in N. Funk and M. Mueller (eds), Gender Politics and Post-Communism: Reflections from Eastern Europe and the former Soviet Union (pp. 95-108). London: Routledge.

Imre, A. (2017). Gender, socialism, and European film cultures, in K. L. Hole, et al. (eds), The Routledge Companion to Cinema and Gender (pp. 88-97). Milton Park, Abingdon, Oxon: Routledge. 
Imre, A. (2007). 'Affective nationalism' and transnational postcommunist lesbian visual activism, in K. Marciniak, A. Imre and Á. O'Healy (eds), Transnational Feminism in Film and Media (pp. 147-162). Comparative Feminist Studies Series. Palgrave Macmillan, New York

Imre, A. (2003). Twin pleasures of feminism: Orlando Meets My Twentieth Century. Camera Obscura, 18(3), 177-210.

Iordanova, D. (2003). Cinema of the Other Europe: The industry and artistry of East Central European film. London: Wallflower Press.

Johnston, C. (1999). Women's cinema as counter-cinema, in S. Thornham (ed), Feminist Film Theory. A reader (pp. 31-40). Edinburgh: Edinburgh University Press.

Kennedy, M. D. (2002). Cultural Formations of Postcommunism: Emancipation, transition, nation, and war. Minneapolis: University of Minnesota Press.

Koutsourakis, A. (2018). Rethinking Brecbtian Film Theory and Cinema. Edinburgh: Edinburgh University Press.

Kraskowska, E. (2012). Feminism Polish style: Our tradition or a borrowed one?, in U. Chowaniec and U. Phillips (eds). Women's Voices and Feminism in Polish Cultural Memory (pp. 67-75). Newcastle upon Tyne, UK: Cambridge Scholars Publishing.

Kristeva, J. (1982). Powers of Horror: An essay on abjection. New York: Columbia University Press.

Lyotard, J. (1984). The Postmodern Condition: A report on knowledge. Manchester: Manchester University Press.

Mansfield, N. (2000). Subjectivity: Theories of the self from Freud to Haraway. New York: New York University Press.

Marciniak, K. (2008). Palatable foreignness, in K. Marciniak et al. (eds), Transnational Feminism in Film and Media (pp. 187-205). Basingstoke: Palgrave Macmillan.

Marsch, R. (2012). Polish feminism in an East-West context, in U. Chowaniec and U. Phillips (eds), Women's Voices and Feminism in Polish Cultural Memory (pp. 47-66). Newcastle upon Tyne, UK: Cambridge Scholars Publishing.

Mazierska, E. (2007). Polish Postcommunist Cinema. From pavement level. Oxford: Peter Lang.

Mazierska, E. and E. Ostrowska (2006). Women in Polish Cinema. New York: Berghahn Books.

Milić, A. (1993). Women and nationalism in the former Yugoslavia, in N. Funk and M. Mueller (eds), Gender Politics and Post-Communism: Reflections from Eastern Europe and the former Soviet Union (pp. 109-122). London: Routledge.

Moss, K. and M. Simić, M. (2011). Post-communist lavender menace: Lesbians in mainstream East European film. Journal of Lesbian Studies 15(3): 271-283. DOI: 10.1080/10894160.2011.530143.

Mulvey, L. (1975). Visual pleasure and narrative cinema, Screen 16(3), 6-18.

Ostrowska E. and Rydzewska, J. (2018). Developments in Eastern European cinemas since 1989, in R. Stone et al. (eds) The Routledge Companion to World Cinema (pp. 167-180). London, New York: Routledge.

Parvulescu, C. and Turcus, C. (2018). Editorial. Studies in Eastern European Cinema, 9(1), 1-2. DOI: 10.1080/2040350X.2017.1421739.

Pitassio, F. (2017). Popular nostalgia: On alternative modes of popular cinema in post-89 Czech production, in D. Ostrowska et al. (eds) Popular Cinemas In East Central Europe: Film cultures and histories (pp. 215-232). London: I. B. Tauris and Co.

Podsiadło, M. (2009). Seksualność kobiet w kinie polskich reżyserek filmowych po roku 1989, in S. Jagielski and A. Morstin-Popławska (eds), Ciało i seksualność w kinie polskim (pp. 79-96). Kraków: Wydawnictwo Uniwersytetu Jagiellońskiego.

Portugese, C. (2007). Central European twins: Psychoanalysis and cinema in Ildikó Enyedi’s My Twentieth Century. Psychoanalytic Inquiry, 27(4), 525-539. DOI: 10.1080/07351690701484675.

Silova, I. (2010). Re-discovering post-socialism in comparative education, in I. Silova (ed.), Post-socialism is Not Dead: (Re)reading the global in comparative education (pp. 1-20). Bingley, UK: Emerald.

Skrodzka, A. (2012). Magic Realist Cinema in East Central Europe. Edinburgh: Edinburgh University Press.

Stachówna, G. (2001). Suczka, Cycofon, Faustyna i inne kobiety w polskim filmie lat dziewiećdziesiątych, in M. Radkiewicz (ed), Gender w bumanistyce (pp. 51-63). Kraków: Rabid.

Stevenson, M. (2000). 'I don't feel like talking to you anymore': Gender uncertainties in Polish Film since 1989. An analysis of Psy (W. Pasikowski 1992), in E. Oleksy, et al (eds), Gender in Film and the Media: East-West dialogues (pp. 134-145). Frankfurt am Main: Peter Lang.

Stojanova, Ch. (2006). Post-communist cinema. The politics of gender and genre, in L. Badley, et al. (eds), Traditions in World Cinema (pp. 95-114). Edinburgh: Edinburgh University Press.

Szczuka, K. (2004). Milczenie onieczek. Warszawa: W.A.B.

Szczuka, K. (2010) Plac Zbawiciela Krzysztofa Krauzego i Joanny Kos-Krauze, czyli kobieta jako parias, in A. Wiśniewska and P. Marecki (eds), Kino polskie, 1989-2009: historia krytyczna (pp. 191-204). Warszawa: Wydawnictwo Krytyki Politycznej.

Tóth, O. (1993). No envy, no pity, in N. Funk and M. Mueller (eds), Gender Politics and Post-Communism: Reflections from Eastern Europe and the former Soviet Union (pp. 213-223). London: Routledge.

Wejbert-Waşiewicz, E. (2018). Problematyka niechcianej ciazi i aborcji w filmie polskim. Ideologia, polityka, rzeczywistosć. Sztuka i Dokumentacja, 18, 259-272. 
Zielińska, A. (2010). State power and the body: The (anti-)abortion legacies of communist Romania and postcommunist Poland in 4 Months, 3 Weeks, and 2 Days and Nothing, in P. Hanáková and K. B. Johnson (eds), Visegrad Cinema: Points of contact from the new waves to the present. Praha: Casablanca.

Citation: Ostrowska, E. (2020). Reluctant Feminists, Powerless Patriarchs, and Estranged Spectators: Gender in Post-1989 Eastern European Cinema. Feminist Encounters: A Journal of Critical Studies in Culture and Politics, 4(2), 32. https://doi.org/10.20897/femenc/8520

Copyright (C) 2020 by Author/s and Licensed by Lectito BV, Netherlands. This is an open access article distributed under the Creative Commons Attribution License which permits unrestricted use, distribution, and reproduction in any medium, provided the original work is properly cited. 